\title{
Qualitative indicators of grain flakes of functional purpose
}

\section{Svitlana Bazhay-Zhezherun, Galyna Simakhina, Ludmyla Bereza-Kindzerska, Nataliia Naumenko}

\author{
National University of food Technologies, Kyiv, Ukraine
}

\section{Keywords:}

Activation

Wheat

Triticale

Oats

Flakes

\section{Article history:}

Received

03.09.2018

Received in revised

form 19.10.2018

Accepted

28.03.2019

\section{Corresponding}

author:

Svitlana Bazhay-

Zhezherun

E-mail:

Lananew_1@

ukr.net

DOI:

$10.24263 / 2304-$

974X-2019-8-1-3

\section{Abstract}

Introduction. Cereal raw materials are an important basis for the food industry. The research was carried out on the possibility of using a whole biologically activated grain of cereals to create functional food products.

Materials and methods. Compoundings of grain mixes of flakes and ready-made products on their basis is investigated. Protein was determined by Biuret method, starch content by polarimetric method. Fat was determined by the method of exhaustive extraction with chemically pure hexane. Vitamin E and substances with P-vitamin activity are determined colorimetrically. Vitamin $\mathrm{C}$ was carried out using a titrimetric method. The microbiological indices of the studied samples were determined by sowing them surface on agarized nutrient media.

Results and discussion. The influence of temperature regime and duration of cold conditioning of grain on its biological value is determined. With change of temperature regime to $12-18{ }^{\circ} \mathrm{C}$ and the duration of conditioning of 24-30 h, the content in the grain of all water-soluble vitamins increases by $2-2,5$ times, the amount of tocopherol grows by 5-7 times, the amount of substances with Pvitamin activity increases in 2,5 times.

The dependence of basic physical and technological parameters of grain flakes and organoleptic properties of finished products from their component composition is investigated. Increase in a mass fraction of oats to $50 \%$ leads to increased viscosity of porridge, due to an increase in the content of hemicellulose, decreases crumbility. Increasing the mass fraction of wheat grain to $35 \%$ leads to a more rigid structure of porridge, which is explained by the higher density of shell parts of wheat grain, compared with other components.

The degree of maintenance of the daily needs of the adult population in the macronutrients, at the expense of consumption of 100 grams of flakes, is: proteins $-18-22 \%$, fats $-5-7 \%$, carbohydrates $13-16 \%$, food fibers $-13,5 \%$.

Taking into account the daily requirement of adult population in vitamins, $100 \mathrm{~g}$ of flakes mix allows you to meet the need for vitamin E by $67-76 \%$; P by $17,4 \%$.

The total number of colony-forming units of mesophilic aerobic and facultative-anaerobic microorganisms in fresh samples of mixes of flakes and after their storage does not exceed $2 \cdot 10^{3}$ per g product, mold mushrooms and pathogenic microorganisms are absent.

Conclusions. Biologically activated grain of cereal cultures of wheat, bare grain oats and triticale is a source of valuable nutrients, for creation of mixes of flakes of functional purpose. 


\section{Introduction}

Cereal products are the main and irreplaceable components of food ration [1], they contain a number of essential substances necessary for providing of the normal functioning of man organism [2]. The leading place of food products on a grain basis in the feed puts the goal of the technologists to achieve a higher level of their functional significance [3]. Scientists investigate the possibility of application new non-traditional types of raw materials, processing methods for improving the quality of food products [4].

Wide distribution is acquired by flakes and groats of quick-cooking [5]. The interest of consumers in this type of products is explained by the possibility of reducing their cooking time and the best food and taste properties, in comparison with traditional groats [1]. The classic type of cereals for the production of flakes is an oat [6]. Lately for the production of flakes apply the row of other cereal cultures - rye, wheat, barley, and also corn, millet, buckwheat as well [5]. This allows you to expand the assortment of products, increase its food value.

One of the most useful and delicious types of cereal products are mueslis, basis of that are the flakes of a several cereals, complemented by fruit and vegetable components [7]. So fairly successful are products that provide a combination of cereal flakes with different original fillings, which is from $30 \%$ to $50 \%$ of the product [5].

The literature does not contain data on the possibility of production of flakes based on biologically activated grain of wheat, bare grain oats and triticale.

\section{Literature review}

By a base product that is basis for the production of flattening groats and flakes there are groats not ground up. Flakes produce from the groats of top grade at their additional cleaning, steaming-out and flattening [6].

Studies have found that regular consumption of whole grains and products on its basis contributes to reducing the risk of diseases of the cardiovascular [1] and digestive systems of the body, the development of diabetes [2].Such influence is caused by the presence in the whole-grain products of a number of biologically active components: vitamins, mineral compounds, food fibers [7] that can increase the immunity and adaptive capacity of a person, improve the activity of the gastrointestinal tract, organs and systems, and reduce the development of metabolic syndrome [3]. It is proved that valuable difficult complexes contained in whole grain products are more useful than the separate isolated components [4]. The peripheral parts of the grain, the shell and the aleurone layer, the germ contain much more valuable micronutrients than the starch endosperm, in particular vitamins and vitaminlike compounds, phenolic compounds, phytosterols, lignans, and dietary fibers [8] that are characterized by high biological activity [9]. It is also known that the proteins of the aleuronic layer and the germ have a higher nutritional value, compared to the grain endosperm proteins [10].

Foods on the basis of grain cereals are the important dietary sources of antioxidants [2]. The authors have investigated that the content of phenolic compounds, in particular routine, quercetin, phenolic acids in grain, not cleaned from shells, is significantly higher, antioxidant activity is also 2-4 times higher than that of grain cleaned from shells [11]. The total content of antioxidants in whole-wheat products exceeds 3,5-6 times the corresponding value in fruits and vegetables [12]. 
Clinical trials by Swiss physicians have shown that whole grains groats reduce the risk of oral and pharyngeal cancers, esophagus and larynx, unlike refined grain products that can contribute to this disease [13].

Scientists confirm the protective role of whole grains products that contain food fiber and the necessary mineral compounds, in particular magnesium, in relation to development of diabetes, especially in the elderly [3]. Clinical researches have shown that low concentration of magnesium in plasma of blood are associated with insulin resistance; it is proved that wholegrain products significantly reduce glycemia [14].

The Polish scientists have analyzed the assortment of the most popular cereal wheat breakfasts. It is marked that these products are made from the grain released from shells were characterized by low protein content (about 6,2\%), subzero content squirrel (close 6,2\%), low total fiber content $(6,49 \%)$ and soluble dietary fibers [5].

Sprouting of grain and seeds is used to soften the core, increasing the nutritional value, reducing anti-alimentary substances and improving the functional composition of proteins [6]. The germination process should be short-lived and carried out at low temperatures, as it results in the degradation of $\beta$-glucans that significantly affect blood cholesterol and glucose, activity of the cardiovascular system, are antibacterial, antitumor, radioprotective properties [15]. So with the germination of oats grain for $72 \mathrm{~h}$, the content of $\beta$-glucans is reduced by $40-45 \%$ [15].

Germination assists the increase of bioavailability of food compounds, by their partial hydrolysis, mineral substances of whole grain of $\mathrm{Fe}$ and $\mathrm{Zn}$, mastering of that is complicated through the presence of natural inhibitors [16], and also to the decline of activity of present antialimentary substances, such as inhibitors of enzymes, hemagglutinins, etc. [17].

Scientists propose to receive flour of high nutritional value, in particular, with improved amino acid, mineral and fatty acid composition of grains germinated in solutions of sea salt [18].

In order to increase the nutritional value of products, biologically activated grain of wheat is recommended for use in bread technology [19]. Scientists from Belarus developed a number of methods for processing biologically activated grain, for the production of flour, groats and other products of high food value [20]. Technology of flakes is worked out from red rice, that envisages the use of whole grain soaked during a few days, that assists the increase of food value and comprehensibility of raw material [21].

The objectives of the work is the scientific and practical ground of the expediency of using a whole biologically activated grain of wheat, bare grain oats and triticale to create a mixture of flakes of high food value.

Task of researches are the following:

- to propose regimes for the preparation of grain of cereal cultures to increase its nutritional value;

- to ground expediency of application of the biologically activated grain-growing raw material for modeling and creating mixtures of flakes of functional purpose;

- to investigate the influence of the composition of the formula of a mixture of flakes on the basis of biologically activated grain of wheat, triticale, and bare grain oats on the basic physical and technological parameters of the product;

- to determine the organoleptic parameters and the nutritional value of grain flakes;

- to investigate the basic indexes of quality of flakes on the basis of biologically activated grain;

- to calculate the provision of day's norm in vitamins and basic substances due to the consumption of mixture of grain flakes;

- to define the indexes of microbiological stability of the product. 


\section{Materials and methods}

\section{Materials}

During realization of experimental researches used grain of wheat, triticale and bare grain oats, respectively, sorts Mironivska 137, Molfar, Solomon [22], to the harvest of 2017; made standards of mixtures of flakes.

\section{Methods of determination of nutrition value of flakes.}

Preparation of investigated samples of flakes envisaged grain cleaning, washing and disinfection, hydrothermal treatment at $12-16^{\circ} \mathrm{C}$ in three cycles, each of which included the intensive moistening of grain for 4 hours, followed by evaporation for 4 to 6 hours, the total duration of 26-30 h. [23], rolling of grain, drying at a temperature of $40-45^{\circ} \mathrm{C}$ to a humidity of $12-14 \%$; combination according to the formulation [6]. Humidity of the investigated samples was determined by drying to a constant mass for temperatures $105^{\circ} \mathrm{C}$ [6]. Protein content was determined by Biuret method [24], which is based on the properties of proteins in an alkaline environment to form a blue-violet color with a biuret reagent whose intensity is determined on a spectrophotometer; starch - polarimetric method [25]. Fat was determined by the method of exhaustive extraction with chemically pure hexane [26]. Vitamins E and P were determined colorimetrically [27], determination of vitamin $\mathrm{C}$ was performed by titrimetric method. The method is based on extracting vitamin $\mathrm{C}$ from the test sample with an acid solution (chloride acid, metaphosphorus or a mixture of acetic and metaphosphoric) followed by titration visually or potentiometrically with sodium 2,6dichlorophenolindophenolate solution [28].

\section{Method of determination of microbiological indicators of flakes}

The microbiological indexes of mixture of flakes determined in the prepared samples, humidity of that folded $11-12 \%$. For this purpose, the samples studied were planted superficially on agarified nutrient media: meat-peptic agar (detection of mesophilic aerobic and facultative anaerobic microorganisms - MAFAnM), wort-agar (yeast and mushrooms). Cups with crops were incubated for 2 to 3 days at a temperature of $37^{\circ} \mathrm{C}$ to establish a total amount $\mathrm{m} / \mathrm{o}$ (MAFAnM). Crops on cups with an environment a wort-agar for the exposure of mushrooms and yeasts were incubated at $28^{\circ} \mathrm{C}$ during a 5-7 days [29].

\section{Results and discussion}

\section{Researches of influence of prescription composition of grain flakes on their indicators of quality}

Scientists have shown that the consumption of grain products plays an important role in maintaining a normal body mass index, providing the body with energy, mineral compounds, vitamins, and lowering cholesterol levels in the blood [30]. Effective are biological methods of preparation of grain raw materials, which contribute to the increase of activity of native enzymes - soaking, sprouting, hydrothermal treatment at low temperatures, fermentation. Such treatment contributes to the highest natural degradation of anti-nutrients - phytate, inhibitors of digestive enzymes, increasing the bioavailability of macronutrients. The use of 
biologically activated grain of cereals for the creation of products for health and functional purposes is a new progressive trend.

Traditional grain preparation includes hydrothermal treatment, in particular, cold conditioning, involves moisture of the grain and prolonged evaporation at a temperature of 30 to $40{ }^{\circ} \mathrm{C}$. Hydrothermal treatment regimes include steam under pressure and grain tempering [31]. Such heating does not contribute to the synthesis of vitamins in the grain.

We have scientifically substantiated and proposed the use of significantly lower temperatures in the cold condition of grain $-12-18^{\circ} \mathrm{C}$. The process of treatment it is recommended to conduct in three cycles, each of which involves intensive humidification of grain for 4 hours, followed by evaporation for 4 to 6 hours, the total duration of 24-30 h, which contributes to increasing of humidity of grain to $30-35 \%$. Such preparation causes activation of the enzyme complex. As a result of the intensification of enzymatic processes, increasing the bioavailability of carbohydrates and proteins, activating the synthesis of vitamins and vitamin-like substances [15]. Due to the activation of the enzyme complex, biological changes occur in the structure of the grain, it begins to sprout, is in the so-called "awakened state" [20]. By this treatment, the content of valuable micronutrients increases significantly, which is related to the internal biological processes in the plant organism.

Our previous investigations have shown that for this treatment, the content of all watersoluble vitamins increases by 2-2,5 times, the amount of tocopherol increases 5-7 times, depending on the culture and sort of grain; substantially increases the content of vitamin-like substances, in particular, substances with P-vitamin activity, inositol, in comparison with grain native [32].

Taking into account principles of health feed, the row of compounding of mixtures of flakes is worked out with the use of grain of wheat, bare grain oats and, triticale. Including our experimental data and applying the calculated method of food combinatorics, the percentage content of the formulation components of the mixture is calculated, which provides the highest amount of vitamins $\mathrm{B}$, vitamins $\mathrm{C}$ and $\mathrm{E}$, inositol in the finished product.

Prepared prototype finished products and studied their basic quality indicators (Table $1)$.

The influence of the amount of components of the mixture of flakes on the quality parameters of the finished product is investigated. It has been experimentally found that flakes obtained from the grain mixture, which include $30-45 \%$ oats, $20-30 \%$ wheat and 35 $40 \%$ triticale are as friable, have a pleasant taste and a smell of cooked flakes. An increase in the mass fraction of oat to $50 \%$ leads to an increase in the viscosity of porridge, due to an increase in the content of hemicellulose, the scatteriness decreases, which is not expedient. Increasing the mass fraction of wheat grain up to $35 \%$ leads to a more rigid structure of porridge, which is explained by the higher density of the shell parts of wheat grain compared to the bare grain of oats and triticale, which is not appropriate.

It was investigated that the ratio of the main constituents of substances in developed grain flakes, which makes $12,2-12,7 \%$ (proteins): $3,8-4,4 \%$ (fats): $54,4-57 \%$ (carbohydrates) is more acceptable than in a number of cereals: manna, wheat, rice and the most popular types of cereal wheat breakfast $[5,33]$.

There was experimentally determined that the content of food fibers in developed grain flakes is $2.7-2.9 \%$. It is researched that according to the water-holding ability, the data of the food fibers belong to the group of medium-water-binding, they have a positive influence on the processes of digestion, occupy a considerable volume in the intestine and increase its peristalsis [13]. The presence of food fibers, which are natural food sorbents, capable of adsorbing toxic substances, heavy metal salts, radionuclides, bile acids, and cholesterol, are an important factor in their functional action on the human body [34]. 
Table 1

Recipes of mixes of flakes and a characteristic of their nutritional value and organoleptic indicators

\begin{tabular}{|c|c|c|c|c|c|c|c|c|c|c|}
\hline \multirow[t]{2}{*}{ № } & \multicolumn{3}{|c|}{$\begin{array}{c}\text { Recipe } \\
\text { components }\end{array}$} & \multicolumn{4}{|c|}{ Nutritional value } & \multicolumn{2}{|c|}{$\begin{array}{c}\text { Vitamin } \\
\text { content, } \\
\text { mg\%. }\end{array}$} & \multirow[b]{2}{*}{$\begin{array}{c}\text { Organoleptic } \\
\text { indicators of } \\
\text { the finished } \\
\text { product }\end{array}$} \\
\hline & $\sum_{\overparen{E}}^{\stackrel{\Xi}{*}}$ & 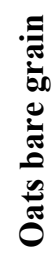 & 窇 & : & 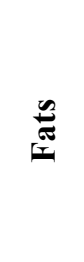 & 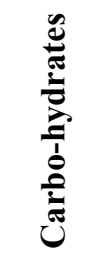 & 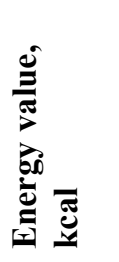 & $\mathbf{E}$ & $\mathbf{P}$ & \\
\hline 1 & 15 & 50 & 35 & 12,85 & 4,58 & 46,25 & 277,45 & 11,85 & 8,57 & $\begin{array}{l}\text { The porridge is } \\
\text { viscous, not } \\
\text { crumbly enough, } \\
\text { the smell and } \\
\text { taste is } \\
\text { characteristic of } \\
\text { this product }\end{array}$ \\
\hline 2 & 20 & 45 & 35 & 12,68 & 4,38 & 47,26 & 279,2 & 11,65 & 8,64 & $\begin{array}{l}\text { Porridge is a } \\
\text { measure of } \\
\text { crumbly, } \\
\text { pleasant taste } \\
\text { and a smell of } \\
\text { cooked flakes }\end{array}$ \\
\hline 3 & 25 & 40 & 35 & 12,51 & 4,18 & 48,26 & 280,74 & 11,55 & 8,74 & $\begin{array}{l}\text { Porridge is a } \\
\text { measure of } \\
\text { crumbly, } \\
\text { pleasant taste } \\
\text { and a smell of } \\
\text { cooked flakes } \\
\end{array}$ \\
\hline 4 & 30 & 30 & 40 & 12,22 & 3,79 & 50,17 & 283,67 & 11,36 & 8,84 & $\begin{array}{l}\text { Porridge is a } \\
\text { measure of } \\
\text { crumbly, } \\
\text { pleasant taste } \\
\text { and a smell of } \\
\text { cooked flakes } \\
\end{array}$ \\
\hline 5 & 35 & 35 & 30 & 12,29 & 3,96 & 49,37 & 282,42 & 11,45 & 8,78 & $\begin{array}{l}\text { The porridge is } \\
\text { hardened with } \\
\text { slipping, the } \\
\text { smell and taste } \\
\text { is characteristic } \\
\text { of this product }\end{array}$ \\
\hline
\end{tabular}




\section{Determination of biological value and physical-technological indicators of quality of grain flakes}

We have determined the content of vitamins in grain flakes. The developed product, due to the preliminary preparation of grain - biological activation, during which the grain sprouts, contains a significantly higher amount of antioxidants - vitamins C, E and substances with $\mathrm{P}$ vitamin activity, compared with traditional grain products. These data are consistent with studies by other scientists who have found a significant increase in the content of vitamins at grain germination $[35,36]$. The flakes also contain vitamins of group B: thiamine -0.48 to $0.62 \mathrm{mg} \%$, riboflavin 0.25 to $0.32 \mathrm{mg} \%$, pyridoxine 0.86 to $1.2 \mathrm{mg} \%$, inositol 154 to $162 \mathrm{mg} \%$ nicotinic acid $-4.5-6.3 \mathrm{mg} \%$.

The basic physical and technological parameters of quality of flakes mixes from biologically activated grain are determined (Table 2).

\section{Physical and technological indicators of grain flakes quality}

Table 2

\begin{tabular}{|l|l|l|l|l|}
\hline \multirow{2}{*}{ № } & Indicator & \multicolumn{3}{|l|}{$\begin{array}{l}\text { The ratio of the formulation components of the } \\
\text { mixture flakes (wheat: oats: triticale), \%. }\end{array}$} \\
\cline { 3 - 5 } & & $\mathbf{2 0 : 4 5 : 3 5}$ & $\mathbf{2 5 : 4 0}: \mathbf{3 5}$ & $\mathbf{3 0}: \mathbf{3 0}: \mathbf{4 0}$ \\
\hline 1. & Humidity, $\%$. & 11,5 & 12,0 & 11,8 \\
\hline 2. & Volumetric mass, g/l & 420 & 426 & 438 \\
\hline 3. & $\begin{array}{l}\text { The middle particle size } \\
\text { mm }\end{array}$ & 5,2 & 6,0 & 6,4 \\
\hline 4. & $\begin{array}{l}\text { The angle of the natural } \\
\text { inclination, deg }\end{array}$ & 64 & 62 & 65 \\
\hline 5. & $\begin{array}{l}\text { Angle of sliding on } \\
\text { metal, deg }\end{array}$ & 15 & 16 & 18 \\
\hline 6. & Actual density, g / & 432 & 440 & 454 \\
\hline 7. & Cohesiveness & 1,1 & 1,2 & 1,4 \\
\hline
\end{tabular}

It should be noted that the ratio of individual components of the mixture of flakes influences the physical and technological parameters [6]. All samples have a permissible value of humidity. The middle particle size of a mixture of flakes depends on the grain size of the raw material and is in the range acceptable for food products on grain basis [31]. The values of indexes of by volume mass and actual density indicate the high quality of the grain product. Optimum values of cohesiveness of grain mixtures characterize their ability to move freely when unloaded from containers and during transportation [6]. The obtained results correlate with the data, determined on the physical and technological parameters of corn flakes [37, 38].

Scientists note that whole grain products are essential for daily diets; they contain a unique set of nutrients that are prevention of cardiovascular disease and diabetes [37].

Using the norms of human physiological needs in the main nutrients and energy [39], the calculation of maintenance of the day's norm (DN) in vitamins and basic substances was made due to the consumption of a mixture of flakes from biologically activated grain. Quantitative indicators are given in tables 3,4. 
Providing daily need for vitamins per $100 \mathrm{~g}$ of a mixture of flakes

\begin{tabular}{|c|c|c|c|c|c|}
\hline \multirow[t]{2}{*}{ Vitamin } & \multirow{2}{*}{$\begin{array}{l}\text { Content in a } \\
\text { mixture of } \\
\text { flakes, mg }\end{array}$} & \multicolumn{2}{|c|}{$\begin{array}{c}\text { Norms of } \\
\text { consumption, mg }\end{array}$} & \multicolumn{2}{|c|}{ Maintenance DN, \% } \\
\hline & & Men & Women & Men & Women \\
\hline $\mathrm{E}$ & 11,5 & 17 & 15 & 67,6 & 76,6 \\
\hline $\mathrm{P}$ & 8,7 & \multicolumn{2}{|c|}{50} & 17,4 & 17,4 \\
\hline $\mathrm{C}$ & 4,2 & \multicolumn{2}{|c|}{70} & 6 & 6 \\
\hline
\end{tabular}

Consequently, taking into account the day's requirement of adult population in vitamins, $100 \mathrm{~g}$ of mixture of flakes allows you to meet the need for vitamin $\mathrm{E}$ by $67-76 \%$ and vitamin $\mathrm{P}$ by $17,4 \%$ and vitamin $\mathrm{C}$ by $6 \%$. The obtained results indicate that a mixture of flakes from biologically activated wheat, oats and triticale is a functional product [40]. These products are able to provide the body with vitamins antioxidants every day, which is important in antioxidant protection of the body [41].

Nutritional and energy value of a mixture of flakes

Table 4

\begin{tabular}{|c|c|c|c|c|c|c|}
\hline \multirow{2}{*}{\multicolumn{2}{|c|}{ Indicator }} & \multirow[t]{2}{*}{$\begin{array}{l}\text { Mixture of } \\
\text { flakes }\end{array}$} & \multicolumn{2}{|c|}{$\begin{array}{c}\text { Daily } \\
\text { norms } \\
\text { consumption } \\
\end{array}$} & \multicolumn{2}{|c|}{$\begin{array}{c}\text { Ensuring day } \\
\text { norm, \%. }\end{array}$} \\
\hline & & & Men & Women & Men & Women \\
\hline \multicolumn{2}{|l|}{ Proteins, $g$} & 12,4 & 67 & 55 & 18,5 & 22,5 \\
\hline \multicolumn{2}{|l|}{ Fats, $g$} & 4,03 & 68 & 56 & 5,92 & 7,19 \\
\hline \multirow{2}{*}{$\begin{array}{l}\text { Carbo- } \\
\text { hydrates, g }\end{array}$} & Starch & 52,7 & 392 & 320 & 13,4 & 16,4 \\
\hline & Food fibers & 2,7 & \multicolumn{2}{|c|}{20} & 13,5 & 13,5 \\
\hline \multicolumn{2}{|c|}{ Energy value, kcal } & 327 & 2450 & 2000 & 13,34 & 16,35 \\
\hline
\end{tabular}

It is established that the degree of ensuring of the day's needs of the adult population of the first group of labor intensity in the macronutrients, at the expense of consumption of 100 grams of cereal flakes is: proteins $-18-22 \%$, fats $-5-7 \%$, carbohydrates $-13-16 \%$, food fibers $-13,5 \%$. The presence of a significant amount of food fibers in the flakes is a positive factor, since these natural sorbents lower the level of cholesterol in the blood and the risk of development of tumors of the upper digestive and respiratory tract $[13,42,43]$.

The total number of colony-forming units of mesophilic aerobic and facultativeanaerobic microorganisms (KFU MANFAnM) was determined in the finished mixture of flakes, as well as during storage of the product for 6 months. The results of microbiological studies are presented in Table 5.

As a result of the conducted research it was established that the microbiological seedability of mix flakes on the basis of biologically activated grain of wheat, triticale and oat does not exceed the values of permissible values of microbiological seedability [29], storage of mixtures of flakes during 6 months does not significantly impair their quality, these grain products are safe from the point of view of microbiological purity. 
Table 5

Microbiological indicators of a mixture of flakes based on biologically activated grain

\begin{tabular}{|l|c|l|c|}
\hline \multirow{2}{*}{ Sample } & \multicolumn{3}{|c|}{ Microbiological indicators } \\
\cline { 2 - 4 } & $\begin{array}{c}\text { MAFAnM, } \\
\text { KFU / g, no more }\end{array}$ & $\begin{array}{l}\text { Mold fung, } \\
\text { KFU / g, not } \\
\text { more }\end{array}$ & $\begin{array}{c}\text { Pathogenic } \\
\text { microorganisms, } \\
\text { including Salmonella } \\
\text { in 25 g }\end{array}$ \\
\hline $\begin{array}{l}\text { Cereals, normative } \\
\text { value }\end{array}$ & $5 \cdot 10^{3}$ & 50 & Not allowed \\
\hline $\begin{array}{l}\text { A mixture of flakes } \\
\text { after drying }\end{array}$ & $3 \cdot 10^{2}$ & Not found & Not found \\
\hline $\begin{array}{l}\text { A mixture of flakes } \\
\text { after 6 months } \\
\text { storage }\end{array}$ & $2 \cdot 10^{3}$ & Not found & Not found \\
\hline
\end{tabular}

\section{Conclusions}

According to the results of analytical and experimental studies, the prescription composition of grain flakes on the basis of biologically activated grain of wheat, oats and triticale has been developed. This product has a functional purpose and is essential for a diet, since it enables you to satisfy your daily needs not only in the required macronutrients, but also in important vitamins and food fibers.

\section{References}

1. Anderson J.W. (2003), Whole grains protect against atherosclerotic cardiovascular disease, Proc. Nutr. Soc., pp. 135-142.

2. Okarter N. (2010), Health benefits of whole grain phytochemicals, Crit Rev. Food Sci Nutr., pp. 193-208.

3. Adom K.K., Sorrells R.H. (2003), Phytochemical Profiles and Antioxidant Activity of Wheat Varieties, J. Agric. Food Chem., pp. 7825-7834.

4. Liu R.H. (2004), Potential synergy of phytochemicals in cancer prevention: mechanism of action, J. Nutr., pp. 3479-3485.

5. Rzedzicki Z., Sykut-Domańska E., Popielewicz J. (2008), Quality of wheat breakfast cereals available on the polish market, J. Food Nutr. Sci, 58, pp. 307-312

6. Egorov G.A., Petrenko T.M. (2000), Tekhnologiya muki i krupy, Izdatel'skij kompleks MGUPP.

7. S. Senhofa, E. Straumite, M. Sabovics, D. Klava, R. Galoburda,T. Rakcejeva (2015), The effect of packaging type on quality of cereal muesli during storage, Agronomy Research, 13(4), P.1064-1073.

8. Jacobs D.R., Pereira M.A., Stumpf K., Pins J.J. (2002), Whole grain food intake elevates serum enterolactone, Br. J. Nutr., pp. 111-116.

9. Liukkonen K.H. Katina K., Wilhelmsson A., Myllymäki O., Lampi A.M. (2003). Process-induced changes on bioactive compounds in whole grain rye, Proc. Nutr. Soc., pp. 117-122. 
10. Kazakov E. D., Karpilenko G.P. (2005), Biohimiya zerna i hleboproduktov GIORD, Sankt-Peterburg.

11. Kerienè I., Mankevičienė A., Bliznikas S., Jablonskytė-raščė D., Maikštėnienė S, Česnulevičienè R. (2015), Biologically active phenolic compounds in buckwheat, oats and winter spelt wheat, Zemdirbyste-Agriculture, 102(3), pp. 289-296.

12. Miller, H.E.; Rigelhof, F., Marquart, L., Prakash, A. Kanter, M. (2000), Antioxidant Content of Whole Grain Breakfast Cereals, Fruit and vegetables, J. Am Coll Nutr, pp. 312-319.

13. Levi F, Pasche C, Lucchini F, Chatenoud L, Jacobs DR \& La Vecchia C (2000) Refined and whole grain cereals and the risk of oral, oesophageal and laryngeal cancer, European Journal of Clinical Nutrition, 54, pp. 487-489.

14. Meyer K.A., Kushi L.H., Jacobs D.R., Slavin J.E., Sellers T.A., (2000), Carbohydrates, dietary fiber, and incident type 2 diabetes in older women, American Journal of Clinical Nutrition, 71, pp.921-930.

15. Review A., Havrlentová M., Petruláková Z., Burgárová A., Gago F. (2011), Cereal $\beta$ glucans and their Significance for the Preparation of Functional Foods, Czech J. Food Sci, 29(1), pp. 1-14

16. Sandberg A. (2002), Bioavailability of minerals in legumes, British Journal of Nutrition, 88(3), pp. 281-285.

17. Delcour J., Hosney C. (2010), Principles of Cereal Science and Technology, Geneve.

18. Kravchenko M., Krivoruchko M. (2012), YAkist' boroshna iz zerna pshenici, proroshchenogo u rozchini mors'koï harchovoï soli, Tovari i rinki, 2 p.106-110.

19. Capalova, I. EH., Sotnikov O.M. (1999), Povyshenie biologicheskoj cennosti hleba putem bioaktivacii zerna pshenicy. Vliyanie prorashchivaniya na himicheskij sostav i kachestvo klejkoviny, Hlebopechenie Rossii, 6, pp. 26-27.

20. Sharshunov V.A., Urbanchyk E.N., Kasyanova L.A. (2012), Biotechnology techniques for a more efficient use of the cereal resources of Belarus, Vesti National Academy of Sciences of Belarus, 1., p.101-106.

21. Kanchana. A., Arun A. (2017), A Research On Reminiscence and Acclimation of Oryza Sativa Flakes. Snacks Among Adolescents, Current Research in Nutrition and Food Science, 5(3), pp. 330-337.

22. Donets M.M. (2007), Nasinnytstvo z osnovamy selektsii, Ahrarna osvita, Kyiv.

23. S. Bazhay-Zhezherun, T. Romanovska, M. Antoniuk (2016) Improving the nutritional value of grains by biological activation, Ukrainian Food Journal, 5(3), pp. 476-484.

24. Kononskyi O. I. (2002), Orhanichna khimiia, Vyshcha shkola, Kyiv.

25. Native starch - Determination of starch content - Ewers polarimetric method / International Standard IS0 10520:1997(E), International Organization for Standardization, Geneve, Switzerland.

26. Erickson M. (2005) Deep Frying. Chemistry, Nutrition, and Practical Applications, Urbana, Illinois.

27. Ermakov A.Y. (1987), Metodi byokhymycheskoho issledovonyia rasteniy, Lenynhrad.

28. Majidi M., Hazim Y-ALQubury (2016), Determination of Vitamin C(ascorbic acid) Contents in various fruit and vegetable by UV-spectrophotometry and titration methods, Journal of Chemical and Pharmaceutical Sciences, 9(4), pp. 2972-2974.

29. Food Standards Australia New Zealand (2016), ISBN: 978-0-642-34594-3.

30. Barton B.A., Eldridge A.L., Thompson D., Affenito S.G., Striegel-Moore R.H., Franko D.L., Albertson A.M., Crockett S.J. (2005), The relationship of breakfast and cereal consumption to nutrient intake and body mass index: The National Heart, Lung and Blood Institute Growth and Health Study, J. Am. Diet. Assoc., 105, p.1383-1389. 
31. Egorova E.YU., Obrezkova M.V., Gur'yanov YU.G. (2011), Zerno i zernoprodukty: zerno, muka, krupy. Tekhnologiya i ocenka kachestva, BTI AltGTU, Bijsk.

32. Simakhina G.A., Bazhay-Zhezherun S.A., Mykoliv T.I., Bereza-Kindzerska L.V., Antoniuk M.M. (2017), The Use Of The Biologically Activated Grain Is In Technology Of Health Products, East European Scientific Journal, 4. p.147-153.

33. Taranenko L. (2004), Grechka potribna vsim, Zerno i hlib, 4, pp. 37.

34. Asp N.G. (2001), Development of dietary fiber methodology, Advanced Dietary Fiber Technology Blackwell Science, pp. 77-88.

35. Kim Y. S., Kim J.G., Lee Y.S., Kang I.J. (2005), Comparison of the chemical components of buckwheat seeds and sprouts, J. Korean Soc. Food Sci. Nutr., 34, pp. 81-86.

36. Kim, Sun Ju and Sarker, Md. Zaidul Islam and Suzuki, Tatsuro and Mukasa, Yuji and Hashimoto (2008) Comparison of phenolic compositions between common and tartary buckwheat (Fagopyrum) sprouts, Food Chemistry, 110(4), pp. 814-820.

37. Milenko B. Košutić1, Lato L., Jelena S. (2017), Improving the nutritive characteristics of corn flakes enriched with functional components, Hem. ind., 71(6), pp. 495-502.

38. Slavin, J.L., Jacobs D., Marquart L. (2001), Grain Processing and Nutrition, Clinical Review Biotechnology, 21, pp. 49-66.

39. Pavlotska L.F., Dudenko N.V., Dymytriievych L.R. (2015), Osnovy fiziolohii, hihiieny kharchuvannia ta problemy bezpeky kharchovykh produktiv, Universytetska knyha, Sumy.

40. Ukrainets A.I., Simakhina H.O. (2009), Tekhnolohiia ozdorovchykh kharchovykh produktiv, NUHT, Kyiv.

41. Biel W., Bobko K., Maciorowski R. (2009), Chemical composition and nutritive value of husked and naked oats grain, Journal of Cereal Science, 49, pp. 413-418.

42. Tappy L. (2006), Effects of break fast cereals containing various amounts of beta-glucan fibres on plasma glucose and insulin responses in NIDDM subjects, Diabetes Care, 19, pp. 831-834.

43. Soukoulis Ch., Lebesi D., Tzia C. (2009), Enrichment of ice cream with dietary fibre: Effects on rheological properties, ice crystallisation and glass transition phenomena, Food Chemistry, 115, pp. 665-671. 